\title{
Callus Culture and in vitro Shoot Regeneration from Stem Segments of Endemic and Medicinally Important Caralluma lasiantha (Wight) N.E.Br.
}

\author{
V. Aruna ${ }^{1}$, C. Kiranmai ${ }^{2}$ T. Pullaiah ${ }^{3}$ \\ ${ }^{1}$ Department of Biotechnology, Chaitanya Bharathi Institute of Technology, Hyderabad - 500075, Telangana, India \\ ${ }^{2}$ Department of Biotechnology, Vikrama Simhapuri University, Nellore-524003, Andhra Pradesh, India \\ ${ }^{3}$ Department of Botany, Sri Krishnadevaraya University, Anantapur-515003, Andhra Pradesh, India
}

\begin{abstract}
Present protocol describes callus induction from stem segments and indirect organogenesis of Caralluma lasiantha, an endemic and traditional medicinal plant. Among different media used, MS medium was selected for callus studies as well as for organogenesis based on percentage of response, fresh and dry weight of the callus. Optimum amount of callus was obtained from MS + 2,4-D 3mg/l + BA 0.1mg/l. Maximum response (60\%) of regeneration from callus was observed on MS + BA $1 \mathrm{mg} / \mathrm{l}+2 \mathrm{PP} 0.5 \mathrm{mg} / \mathrm{l}$. In vitro rooting was carried on $1 / 2$ strength MS medium supplemented with NAA $0.1 \mathrm{mg} / \mathrm{l}$ for better survival of plantlets. In vitro regenerated plantlets were successfully established in soil with 70\% survival rate.
\end{abstract}

Keywords: Callus culture, Caralluma lasiantha, organogenesis, in vitro rooting, in vitro propagation

\begin{abstract}
Abbreviations: 2,4-D: 2,4-dichlorophenoxyacetic acid; 2,4,5-T: 2,4,5-trichlorophenoxyacetic acid; 2,4,5-TP: 2,4,5trichlorophenoxypicolinic acid; $\mathrm{B}_{5}$ : Gamborg's medium; BA: 6- benzyl adenine; Dicamba: 3,6-dichloroanisic acid; IAA: Indole-3-acetic acid; IBA: Indole-3-butyric acid; KN: Kinetin; MS: Murashige and Skoog medium; NAA: Naphthalene acetic acid; 2-iP: 2-isopentenyladenine; WPM: Woody Plant Medium; TDZ: Thidiazuron; Zeatin: 4-hydroxy-3-methyl-transbutenylaminopurine.
\end{abstract}

\section{Introduction}

Several plants belonging to the family Asclepiadaceae are used in folkloric medicine as well as in ancient system of medicine like Ayuveda and Unani. Caralluma species have been used as emergency foods for centuries in semi-arid areas of African countries, Pakistan and India. Caralluma lasiantha (Wight) N.E.Br. belongs to the family Asclepiadaceae. It is a thick, erect, leafless, succulent, perennial herb with a sour taste, occurring wild in rocky and dry southern parts of south India. The species of Caralluma found in India are edible and form a part of the traditional medicine system of the country. Plants belonging to the genus Caralluma are rich in esterified polyhydroxy pregnane glycosides, some of which showed antitumour activity and others were postulated as precursors of cardenolides (Deepak et al., 1989, 1997). Rizwani et al. (1990) and Ramesh et al. (1999) reported the presence of flavone glycosides. From the whole plant, two new bisdesmosidic C-21 steroidal (pregnane) glycosides, named lasianthoside -A and -B were isolated by Qiu et al. (1999). In addition, a known flavonoid glycoside, luteolin neohesperidoside was also isolated by Ramesh et al. (1999).

Some of the ingredients which are used in the preparation of drugs are obtained from Caralluma. Due to indiscriminate collection and over exploitation for commercial purposes and to meet the requirements of the pharmaceutical industry natural stands are fast disappearing and are threatened with extinction. There are no cultivation techniques for this endemic succulent medicinal plant till now. For conservation of medicinal Caralluma species, in vitro protocol are already developed for Caralluma edulis (Kaur et al., 1992), Caralluma adscendens (Aruna et al., 2009), Caralluma sarkariae (Sreelatha et al., 2009), Caralluma bhupenderiana (Ugraiah et al., 2011), Caralluma tuberculata (Rehman et al., 2014) and Caralluma pauciflora (Kiranmai et al., 2015). We earlier described micropropagation method using nodal explants of Caralluma lasiantha (Aruna et al., 2012). In the present paper we report a prime protocol for the shoot regeneration from callus culture of Caralluma lasiantha via organogenesis.

\section{Material and Methods}

Caralluma lasiantha was collected from Gooty hills, Anantapur district, Andhra Pradesh, India and was potted in $15 \mathrm{~cm}$ diameter pots and maintained at Sri Krishnadevaraya University garden, Anantapur. The plants were grown at 30$35^{\circ} \mathrm{C}$ with natural day light and irrigated with water as required. Young shoots of Caralluma lasiantha plants which are grown in the pots were used as explant material.

Actively growing shoots with five nodes were used as the source of explants. The shoots were washed under running tap water for 5 minutes, followed by $1 \%$ Tween -20 for 10 min. Shoots were thoroughly washed under running tap water until the traces of Tween - 20 was removed. Remaining steps of surface sterilization was carried out under aseptic conditions in laminar air flow chamber. After washing with sterilized double distilled water surface sterilization was done with Mercuric chloride $(0.1 \%$ w/v) solution for $5 \mathrm{~min}$ and rinsed $4-5$ times with sterilized double distilled water. Explants were then subjected to $70 \%$ 


\section{International Journal of Science and Research (IJSR) \\ ISSN (Online): 2319-7064}

Index Copernicus Value (2013): 6.14 | Impact Factor (2014): 5.611

ethanol treatment for $1 \mathrm{~min}$ and again washed with sterilized double distilled water at least 3 to 4 times. Explants were dissected, damaged ends were removed and blotted on a sterile filter paper disk and inoculated on medium for shoot induction.

Stem segments were cultured on MS (Murashige and Skoog, 1962) medium containing 3\% sucrose and solidified with $0.8 \%$ agar after adjusting the $\mathrm{pH}$ to 5.8 and poured approximately $15 \mathrm{ml}$ per test tube $(150 \times 25 \mathrm{~mm}$, Borosil, India). The tubes were sealed with aluminum foil and sterilized at $121^{\circ} \mathrm{C}$ and $1.06 \mathrm{Kg} \mathrm{cm}{ }^{-2}$ pressure for 15 minutes.

Stem segments were cultured on three different media such as MS, $\mathrm{B}_{5}$ and WPM media supplemented with 2, 4-D 2 $\mathrm{mg} / \mathrm{l}$ for callus initiation. Based on the frequency of response, callus mass and quality the suitable medium was selected for further experiments. Stem segments were cultured on selected medium supplemented with different auxin concentrations of 2,4-dichlorophenoxyacetic acid $(2,4-$ D), 2,4,5-trichlorophenoxyacetic acid (2,4,5-T), 2,4,5trichlorophenoxypicolinic acid (2,4,5-TP), Picloram, 3,6dichloroanisic acid (Dicamba), Indole-3-acetic acid (IAA), Indole-3-butyric acid (IBA), Naphthalene acetic acid (NAA) alone and combinations of cytokinin 6- benzyl adenine (BA), Kinetin (KN), 2-isopentenyladenine (2-iP) for screening best combination for callus production. The cultures were incubated at $25 \pm 2{ }^{\circ} \mathrm{C}$, with irradiance of 50 $\mu \mathrm{mol} \mathrm{m} \mathrm{m}^{-2} \mathrm{~s}^{-1}$ for $16 \mathrm{~h}$ photoperiod.

Organogenic callus was subcultured on MS medium supplemented with different concentrations of cytokinins 6benzyl adenine (BA), Kinetin (KN), 2-iP, 4-hydroxy-3methyl-trans-butenylaminopurine (Zeatin), Thidiazuron (TDZ) either alone or its combinations for shoot development. The developed shoots were further cultured for in vitro rooting to develop into a complete plantlet. Shoots with 4-5 nodes, were excised and used for root initiation in $0.6 \%$ agar gelled medium containing half strength MS salts with $1 \%$ sucrose, incorporated with different concentrations of auxins (NAA, IAA and IBA). After four weeks of culture the shoots with well developed roots were removed from culture medium and washed with sterile distilled water. The plants were transplanted in $5 \square 5$ $\mathrm{cm}$ plastic pots containing sand, farmyard manure and peat moss in 1:1:1 ratio and pots were irrigated with half strength basal liquid medium without sucrose. The plastic pots were covered with a polythene bag to maintain humidity and small holes were made. The width of the holes was slowly increased until the humidity inside and outside the polythene bags comes equal. Later on the polythene bag was removed and well developed plant was further transferred into soil.

The experiments were randomized and the experiment was repeated thrice. Each treatment consists of 15 replicates. Data were statistically analyzed by analysis of variance (ANOVA) and means were compared by Tukey's test at $0.05 \%$ probability level.

\section{Results and Discussion}

\subsection{Callus Induction}

The effect of different basal media supplemented with 2,4-D $2 \mathrm{mg} / \mathrm{l}$ and $3 \%$ sucrose were tested for callus induction in Caralluma lasiantha. MS medium was found to be most effective by producing callus fresh and dry weight of 866.46 $\square 2.53 \mathrm{mg}$ and $40.06 \square 0.47 \mathrm{mg}$ respectively when compared to $\mathrm{B}_{5}$ and WPM. WPM fortified with 2,4-D $2 \mathrm{mg} / \mathrm{l}$ was found to be least effective in initiation of callus. In the present investigation the efficiency of medium for callus induction was in the order of MS $>B_{5}>$ WPM. MS medium was selected for further callus studies as well as for organogenesis based on percentage of response, fresh and dry weight of the callus. MS medium was also found to be effective for callus induction in other members of Asclepiadaceae such as Caralluma pauciflora (Kiranmai et al., 2015)

Caralluma lasiantha stem segments were cultured on MS medium fortified with various concentrations of 2,4-D. 2,4$\mathrm{D}$ at $0.1 \mathrm{mg} / \mathrm{l}, 1 \mathrm{mg} / \mathrm{l}$ and $2 \mathrm{mg} / 1$ produced whitish green compact callus with $35 \%, 55 \%$ and $71 \%$ of response respectively. Brown compact callus resulted when the concentration of 2,4-D was increased to $7 \mathrm{mg} / \mathrm{l}$. Mature stem segments cultured on $2,4,5-\mathrm{T} 0.1 \mathrm{mg} / 1$ and $1 \mathrm{mg} / 1$ produced light green compact callus with $40 \%$ and $48 \%$ of response respectively. Light brown compact callus was produced on $2 \mathrm{mg} / 1,3 \mathrm{mg} / 1$ and $5 \mathrm{mg} / 1$ with $60 \%, 40 \%$ and $35 \%$ response respectively. Similar to 2 , 4-D 7mg/1, 2,4,5-T 7mg/1 also produced brown compact callus. Among different concentration of 2,4,5-TP $0.1 \mathrm{mg} / 1$ produced light green compact callus with $55 \%$ response. When the concentration was increased from $0.1 \mathrm{mg} / 1$ to $7 \mathrm{mg} / 1$, gradual decrease in the percentage of callusing and change in nature of callus was observed.

Stem segments cultured on Picloram $0.1 \mathrm{mg} / 1,1 \mathrm{mg} / \mathrm{l}$ and $2 \mathrm{mg} / \mathrm{l}$ was light green compact in nature. Increased concentration of Picloram produced creamish embryogenic callus with $64 \%$ and $60 \%$ response at $5 \mathrm{mg} / 1$ and $7 \mathrm{mg} / 1$ respectively. Stem segments cultured with different concentration of Dicamba resulted light green compact callus in all treatments with various percentage of response. Maximum percentage of response $(55 \%)$ resulted on Dicamba 3mg/l. Maximum induction of callus was observed at $3 \mathrm{mg} / 1 \mathrm{NAA}$ with $60 \%$ response with stem explant where as at $2 \mathrm{mg} / \mathrm{l}$ NAA $40 \%$ response was observed. Only two concentrations of IAA produced callus with $20 \%$ and $35 \%$ response. In remaining concentration there was no response and explants remained green after 45 days also.

Based on the rate of callus induction and the percentage of response, $3 \mathrm{mg} / 1$ 2,4-D was optimum. Above and below this concentration the rate of callus induction or percentage of cultures responding decreased. Hence further experiments were carried out with $3 \mathrm{mg} / \mathrm{l}$ 2,4-D. Stem segments were cultured on MS basal medium supplemented with 2,4-D $3 \mathrm{mg} / \mathrm{l}$ in combination with BA $(0.1,0.25,0.5,1.0$ and $2.0 \mathrm{mg} / \mathrm{l}), \mathrm{KN}(0.1,0.25,0.5,1.0$ and $2.0 \mathrm{mg} / \mathrm{l})$ and $2 \mathrm{iP}(0.1$, $0.25,0.5,1.0$ and $2.0 \mathrm{mg} / \mathrm{l})$ for callus induction. 


\section{International Journal of Science and Research (IJSR) \\ ISSN (Online): 2319-7064}

Index Copernicus Value (2013): 6.14 | Impact Factor (2014): 5.611

Among various combinations of 2,4-D and BAP, 2,4-D $3 \mathrm{mg} / \mathrm{l}+\mathrm{BA} 0.1 \mathrm{mg} / 1$ produced dark green compact callus with maximum response $(80 \%)$ in Caralluma lasiantha. Increase in the concentration of $\mathrm{BA}$ produced greenish yellow compact callus. Combinations of 2,4-D and $\mathrm{KN}$ produced brown compact callus. Stem segments cultured on MS medium supplemented with 2,4-D 3mg/l + 2iP $0.1 \mathrm{mg} / 1$ produced green compact callus whereas 2,4-D 3mg/1 + 2iP 1 $\mathrm{mg} / \mathrm{l}$ produced creamish friable callus with maximum response (75\%). In a study using Asclepias tuberose, another Asclepiad, Vyapari et al. (1993) demonstrated the need of 2,4-D $2 \mathrm{mg} / \mathrm{l}$ and BA $0.1 \mathrm{mg} / 1$ for callus induction. In another study using Tylophora indica Thomas and Philip (2005) produced callus on 2,4-D and BA. There are reports where optimum callus development was seen on 2,4-D with various cytokinins in Tylophora indica (Faisal et al., 2005).

\subsection{Organogenesis and Regeneration}

Callus obtained from stem segments of Caralluma lasiantha cultured on MS + 2,4-D 3mg/l + BA $0.1 \mathrm{mg} / 1$ was used for shoot bud regeneration. Organogenic callus was observed after 4 weeks of incubation followed by shoot bud initiation. Among different concentrations of cytokinins used for shoot bud regeneration $\mathrm{BA}$ and $2 \mathrm{iP}$ responded, whereas with other hormone combination there was less response. Response was not observed if low concentration of BA and $2 \mathrm{iP}$ were used. Out of various concentrations of BA used, BA $1 \mathrm{mg} / \mathrm{l}$ gave 1.40 shoots with $40 \%$ response. Combinations of cytokinins were also used to induce shoot buds. Caulogenesis was observed after 3 weeks of incubation. Cultures were transferred to fresh medium after three weeks. Shoot bud differentiation was observed with 4.67 shoots on BA $1 \mathrm{mg} / 1+2 \mathrm{iP} 0.5 \mathrm{mg} / 1$ with $60 \%$ response. But there are several reports in Asclepiadaceae where cytokinin and auxins proved to be effective for adventitious shoot bud formation from callus in Ceropegia thwaitesii (Muthukrishnan et al., 2015), Leptadenia reticulata (Patel et al., 2014) and Tylophora indica (Fasial et al., 2005).

\subsection{In vitro rooting of in vitro regenerated shoots and acclimatization}

In Caralluma lasiantha $1 / 2$ MS + NAA $0.1 \mathrm{mg} / 1$ induced 8.73 $\square 0.35$ roots on with $88 \%$ of rooting. However increasing concentrations of NAA induced the formation of short, thick fleshy roots. Although, IAA did not induce callusing, the percentage of rooting and the number of roots formed were poor. Maximum of $4.80 \square 0.22$ roots per shoot were obtained with $4.92 \square 0.04 \mathrm{~cm}$ root length on medium containing IAA $0.5 \mathrm{mg} / 1$. Among different treatments with IBA $2 \mathrm{mg} / \mathrm{l}$ induced $4.53 \square 0.19$ roots per shoot with $2.67 \square$ $0.02 \mathrm{~cm}$ root length. After 45 days of incubation on IBA $2 \mathrm{mg} / \mathrm{l}$ about $16 \mathrm{~cm}$ of root length was observed.

Root induction was possible with all auxins. However survival of plantlets required strong, healthy, long roots, which were obtained from $1 / 2$ MS medium supplemented with NAA $0.1 \mathrm{mg} / \mathrm{l}$. The reason for the reduced survival in higher concentrations of NAA treatments may be due to poor vascular connection of the root with the stem because on the intervention of callus. The positive response of rooting in the present study is similar to observations of other species of Caralluma such as Caralluma adscendens (Aruna et al., 2009), Caralluma sarkariae (Sreelatha et al., 2009), Caralluma bhupenderiana (Ugraiah et al., 2011) and Caralluma pauciflora (Kiranmai et al., 2015).

In vitro regenerated plantlets with well developed shoots and roots were washed with water and were transferred to pots containing peat moss, farmyard manure and soil in 1:1:1 ratio. The potted plants were covered with polythene cover to ensure high humidity and irrigated every three days with $1 / 2$ MS macro salt free of sucrose for 2 weeks. Lowering sucrose percent or omitting it altogether can give faster and more successful acclimatization (Short et al., 1987). The plantlets were maintained in culture room conditions for two weeks. The gradual exposure of plants to conditions outside the polythene covering helped to conserve and develop a proper balance of relative humidity and thereby increased the rate of survival. After two weeks the hardened plantlets were transferred to earthen pots and maintained under shade for one more week. Then plants were exposed to sunlight for few hours for a week and then plants were transferred to soil and watered with tap water. The rooted plants were successfully established in soil with $70 \%$ survival rate in Caralluma lasiantha.

\section{References}

[1] Aruna, V., Kiranmai, C., Karuppusamy, S., Pullaiah, T. 2009. Micropropagation of three varieties of Caralluma adscendens. J. Plant Biochem. Biotech. 18: 121-123.

[2] Aruna, V., Kiranmai, C., Karuppusamy, S., Pullaiah, T. 2012. Effect of medium, explants, cytokinins and node position on in vitro shoot multiplication of Caralluma lasiantha (Wight) N.E.Br. - an endemic and medicinally important plant. African J. Biotech. 11: 15523-15528.

[3] Deepak, D., Khare, A., Khare, M.P. 1989. Plant pregnanes. Phytochemistry. 28: 3255-3263.

[4] Deepak, D., Srivastav, S., Khare, A 1997. Pregnane glycosides. Progress in the chemistry of organic Natural Products. 71: 169-325.

[5] Faisal, M., Singh. S., Anis, M. 2005. In vitro regeneration and plant establishment of Tylophora indica (Burm.f.) Merrill: petiole callus culture. In vitro Cell. Dev. Biol. Plant. 41: 511-515.

[6] Kaur, G., Rathore, T.S., Rama Rao, S., Shekhawat, N. S. 1992. In vitro micropropagation of Caralluma edulis (Edgew.) Benth. \& Hook.f. - a rare edible plant species of Indian desert. Indian J. Plant Gen. Res. 5: 51-56.

[7] Kiranmai, C., Aruna, V., Pullaiah, T. 2015. Somatic embryogenesis and indirect organogenesis of Caralluma pauciflora Wight (Apocynaceae) - An endemic and rare plant. Indian J. Biotech. 14:411-413

[8] Murashige, T., Skoog 1962. A revised medium from rapid growth and bioassays with tobacco tissue cultures. Physiol. Plant. 15: 473-497.

[9] Muthukrishnan, A., Kumar, T. S., Rao, M. V. 2015. An efficient in vitro regeneration and ex vitro rooting of Ceropegia thwaitesii : An endemic species from Western Ghats. Int. J. Pharm. Sci. Rev. Res. 30:202211.

[10] Patel, A.K., Agarwal, T., Phulwaria, M., Kataria, V., Shekhwat, N.S. 2014. An efficient in vitro plant 


\section{International Journal of Science and Research (IJSR) \\ ISSN (Online): 2319-7064}

Index Copernicus Value (2013): 6.14 | Impact Factor (2014): 5.611

regeneration system from leaf of mature plant of Leptadenia reticulata (Jeewanti): A life giving endangered woody climber. Industrial crops and products. 52: 499-505.

[11] Qiu, S.X., Cordell, G.A., Ravi Kumar, B., Nageshwara Rao, Y., Ramesh, M., Kokate, C.K., Appa Rao, A.V.N. 1999. Bisdesmosidic pregnane glycosides from Caralluma lasiantha. Phytochemistry. 50: 485-491.

[12] Ramesh, M., Nageshwara Rao, Y., Rama Kumar, M., Krishna Mohan, G., Ravi Kumar, B., Appa Rao, A.V.N., Radha Kishan, M., Madhava Reddy, B. 1999. Flavone glycoside from three Caralluma species. Biochemical Systematics \& Ecol. 27: 85-86.

[13]Rehman, R.U., Chaudhary, M.F., Khawar, G.L., Mannan, A., Zia, M. 2014. In vitro propagation of Caralluma tuberculata and evaluation of antioxidant potential. Biologia. 69: 341-349.

[14] Rizwani, G.H., Usmanghani, K., Ahmad, M., Ahmad, V.U. 1990. Flavone glycosides of Caralluma tuberculata N.E. Brown. Pakistan J. Pharmaceut. Sci. 3: 27-32.

[15] Short, K.C., Warburton, J., Roberts, A.V. 1987. In vitro hardening of cultured cauliflower and Chrysanthemum to humidity. Acta Hort. 212: 329-334.

[16] Sreelatha, V.R., Sandhya Rani, S., Krishna Reddy, P.V., Naveen, M., Ugraiah, A., Pullaiah, T. 2009. In vitro propagation of Caralluma sarkariae Lavranos \& Frandsen - An endemic and endangered medicinal plant. Indian J. Biotech. 8: 236-239.

[17] Thomas, T.D., Philip, B. 2005. Thidiazuron-induced high frequency shoot organogenesis from leaf derived callus of a medicinal climber, Tylophora indica (Burm. f.) Merrill. In vitro Cell Dev. Biol. Plant. 41: 124-128.

[18] Ugraiah, A., Raja Sreelatha, V., Krishna Reddy, P.V., Rajasekhar, K., Sandhya Rani, S., Karuppusamy, S. and Pullaiah, T. 2011. In vitro shoot multiplication and conservation of Caralluma bhupinderiana Sarkaria - an endangered medicinal plant from South India. Afr. J. Biotech. 10: 9328-9336.

[19] Vyapari, S., Khatamian, H. and Albrecht, M.L. 1993. In vitro regeneration in Asclepias tuberosa L. Hort. Sci. 28: 508 .

Table 1: Influence of different types of media on callus induction from stem segments of Caralluma lasiantha with 2,4-D 2mg/1

\begin{tabular}{|c|c|c|c|c|}
\hline $\begin{array}{c}\text { Plant growth } \\
\text { regulator }(m g / l)\end{array}$ & Medium & $\begin{array}{c}\text { \% of } \\
\text { response }\end{array}$ & $\begin{array}{c}\text { Fresh weight } \\
(m g) \\
\text { Mean } \pm S E\end{array}$ & $\begin{array}{c}\text { Dry weight } \\
(m g) \\
\text { Mean } \pm S E\end{array}$ \\
\hline $2,4-\mathrm{D} 2 \mathrm{mg} / \mathrm{l}$ & $\mathrm{MS}$ & 71 & $866.46 \pm 2.53^{\mathrm{a}}$ & $40.06 \pm 0.47^{\mathrm{a}}$ \\
\hline & $\mathrm{B}_{5}$ & 60 & $366.13 \pm 2.75^{\mathrm{b}}$ & $25.93 \pm 0.27^{\mathrm{b}}$ \\
\hline & $\mathrm{WPM}$ & 55 & $290.53 \pm 3.32^{\mathrm{c}}$ & $24.06 \pm 0.39^{\mathrm{c}}$ \\
\hline
\end{tabular}

Means $\pm \mathrm{SE}, \mathrm{n}=45$. Means followed by the same letter are not significantly different by the tukey test at $0.05 \%$ probability level.
Table 2: Influence of various auxins on callus induction from stem segments of Caralluma lasiantha cultured on MS medium

\begin{tabular}{|c|c|c|c|}
\hline $\begin{array}{l}\text { Plant growth } \\
\text { regulator }(\mathrm{mg} / \mathrm{l})\end{array}$ & $\begin{array}{l}\text { Frequency of } \\
\text { response }(\%)\end{array}$ & $\begin{array}{l}\text { Degree of } \\
\text { Callusing }\end{array}$ & $\begin{array}{c}\text { Nature of } \\
\text { callus }\end{array}$ \\
\hline \multicolumn{4}{|l|}{$2,4-\mathrm{D}$} \\
\hline 0.1 & 35 & + & WGCC \\
\hline 1.0 & 55 & + & WGCC \\
\hline 2.0 & 71 & +++ & WGCC \\
\hline 3.0 & 73 & +++ & GCC \\
\hline 5.0 & 40 & + & YGCC \\
\hline 7.0 & 28 & + & $\mathrm{BCC}$ \\
\hline \multicolumn{4}{|l|}{$2,4,5-\mathrm{T}$} \\
\hline 0.1 & 40 & + & LGCC \\
\hline 1.0 & 48 & ++ & LGCC \\
\hline 2.0 & 60 & +++ & LBCC \\
\hline 3.0 & 40 & + & LBCC \\
\hline 5.0 & 35 & + & LBCC \\
\hline 7.0 & 20 & + & $\mathrm{BCC}$ \\
\hline \multicolumn{4}{|l|}{$2,4,5-\mathrm{TP}$} \\
\hline 0.1 & 55 & ++ & LGCC \\
\hline 1.0 & 46 & ++ & LGCC \\
\hline 2.0 & 40 & + & LGCC \\
\hline 3.0 & 33 & + & GYC \\
\hline 5.0 & 28 & + & YGC \\
\hline 7.0 & 20 & + & YGC \\
\hline \multicolumn{4}{|l|}{ Picloram } \\
\hline 0.1 & 46 & +++ & LGCC \\
\hline 1.0 & 53 & ++ & LGCC \\
\hline 2.0 & 57 & ++ & LGCC \\
\hline 3.0 & 60 & ++ & $\mathrm{CCC}$ \\
\hline 5.0 & 64 & ++ & CEC \\
\hline 7.0 & 60 & ++ & CEC \\
\hline \multicolumn{4}{|l|}{ Dicamba } \\
\hline 0.1 & 37 & ++ & LGCC \\
\hline 1.0 & 40 & ++ & LGCC \\
\hline 2.0 & 46 & ++ & LGCC \\
\hline 3.0 & 55 & +++ & LGCC \\
\hline 5.0 & 40 & ++ & LGCC \\
\hline 7.0 & 35 & ++ & LGCC \\
\hline \multicolumn{4}{|l|}{ NAA } \\
\hline 0.1 & 20 & + & HLGCC \\
\hline 1.0 & 33 & + & HLGCC \\
\hline 2.0 & 40 & ++ & HLGCC \\
\hline 3.0 & 60 & +++ & LGCC \\
\hline 5.0 & 53 & + & GCC \\
\hline 7.0 & 35 & + & GYCC \\
\hline \multicolumn{4}{|l|}{ IAA } \\
\hline 0.1 & - & - & NR \\
\hline 1.0 & 20 & + & SGC \\
\hline 2.0 & 35 & ++ & LGC \\
\hline 3.0 & - & - & NR \\
\hline 5.0 & - & - & NR \\
\hline 7.0 & - & - & NR \\
\hline
\end{tabular}

BCC - Brown Compact Callus; CCC - Creamish Compact Callus; CEC - Creamish Embryogenic Callus; GCC - Green Compact Callus; GYC - Greenish Yellow Callus; GYCC Greenish Yellow Compact Callus; HLGCC - Hairy Light Green Compact Callus; LGC - Light Green Callus; LGCC Light Green Compact Callus; NR - No Response; SGC Scanty Green Callus; WGCC - Whitish Green Compact Callus; YGC - Yellowish Green Callus; YGCC - Yellowish Green Compact Callus

+ Scanty; ++ Less; +++ Moderate; ++++ Profuse; 


\section{International Journal of Science and Research (IJSR) \\ ISSN (Online): 2319-7064 \\ Index Copernicus Value (2013): 6.14 | Impact Factor (2014): 5.611}

Experiments were repeated thrice with 15 replicated each.

Table 3: Influence of 2,4-D 3mg/l in combination with BA, $\mathrm{KN}$ and $2 \mathrm{iP}$ on callus induction from stem segments of Caralluma lasiantha cultured on MS medium

\begin{tabular}{|l|l|l|l|}
\hline Plant growth regulator (mg/l) & Frequency of & Degree of & Nature of \\
\hline
\end{tabular}

\begin{tabular}{|c|c|c|c|c|c|c|}
\hline $2,4-\mathrm{D}$ & BAP & KN & 2iP & response (\%) & Callusing & callus \\
\hline 3 & 0.1 & - & - & 80 & ++++ & DGCC \\
\hline 3 & 0.25 & - & - & 75 & +++ & GYCC \\
\hline 3 & 0.5 & - & - & 66 & +++ & GYCC \\
\hline 3 & 1.0 & - & - & 60 & +++ & GYCC \\
\hline 3 & 2.0 & - & - & 55 & ++ & GYCC \\
\hline 3 & - & 0.1 & - & 40 & + & BCC \\
\hline 3 & - & 0.25 & - & 48 & ++ & BCC \\
\hline 3 & - & 0.5 & - & 55 & ++ & BCC \\
\hline 3 & - & 1.0 & - & 60 & ++ & BCC \\
\hline 3 & - & 2.0 & - & 66 & +++ & GBCC \\
\hline 3 & - & - & 0.1 & 35 & + & GCC \\
\hline 3 & - & - & 0.25 & 46 & ++ & CGC \\
\hline 3 & - & - & 0.5 & 66 & +++ & CCC \\
\hline 3 & - & - & 1.0 & 75 & ++++ & CFC \\
\hline 3 & - & - & 2.0 & 60 & ++ & CFC \\
\hline
\end{tabular}

BCC - Brown Compact Callus ;CCC - Creamish Compact Callus; CFC - Creamish Friable Callus; CGC -Creamish Green Callus; DGCC - Dark Green Compact Callus; GBCC - Greenish Brown Compact Callus

GYCC - Greenish Yellow Compact Callus

+ Scanty; ++ Less; +++ Moderate; ++++ Profuse;

Experiments were repeated thrice with 15 replicated each.
Table 4: Influence of various plant growth regulators on morphogenic response of callus induced from stem segments of Caralluma lasiantha cultured on MS medium

\begin{tabular}{|c|c|c|c|c|c|c|}
\hline \multicolumn{6}{|c|}{ Media used for morphogenesis } & \multicolumn{2}{c|}{$\begin{array}{c}\text { Callus obtained from stem } \\
\text { segments }\end{array}$} \\
\hline BAP & 2 iP & KN & Zeatin & TDZ & $\begin{array}{c}\% \text { of } \\
\text { response }\end{array}$ & $\begin{array}{c}\text { Mean no. of shoot } \\
\text { buds / explant } \pm \text { S.E }\end{array}$ \\
\hline 0.1 & - & - & - & - & - & NR \\
\hline 0.5 & - & - & - & - & - & NR \\
\hline 1 & - & - & - & - & 40 & $1.40 \pm 0.29^{\text {bc }}$ \\
\hline 1 & 0.1 & - & - & - & 53 & $2.33 \pm 0.35^{\mathrm{b}}$ \\
\hline 1 & 0.5 & - & - & - & 60 & $4.67 \pm 0.22^{\mathrm{a}}$ \\
\hline 1 & - & 0.1 & - & - & 35 & $1.20 \pm 0.22^{\mathrm{c}}$ \\
\hline 1 & - & 0.5 & - & - & 30 & $1.10 \pm 0.17^{\mathrm{c}}$ \\
\hline 1 & - & - & 0.1 & - & 33 & $1.07 \pm 0.23^{\mathrm{c}}$ \\
\hline 1 & - & - & - & 0.05 & 35 & $1.33 \pm 0.16^{\mathrm{bc}}$ \\
\hline- & 0.5 & - & - & - & - & $\mathrm{NR}$ \\
\hline- & 1 & - & - & - & 28 & $1.00 \pm 0.24^{\mathrm{c}}$ \\
\hline- & 1 & 0.1 & - & - & 24 & $0.80 \pm 0.24^{\mathrm{c}}$ \\
\hline- & 1 & - & 0.1 & - & 26 & $0.93 \pm 0.15^{\mathrm{c}}$ \\
\hline- & 1 & - & - & 0.05 & 20 & $0.67 \pm 0.19^{\mathrm{c}}$ \\
\hline
\end{tabular}

Means \pm SE, $n=45$. Means followed by the same letter are not significantly different by the Tukey test at $0.05 \%$ probability level; NR -No response

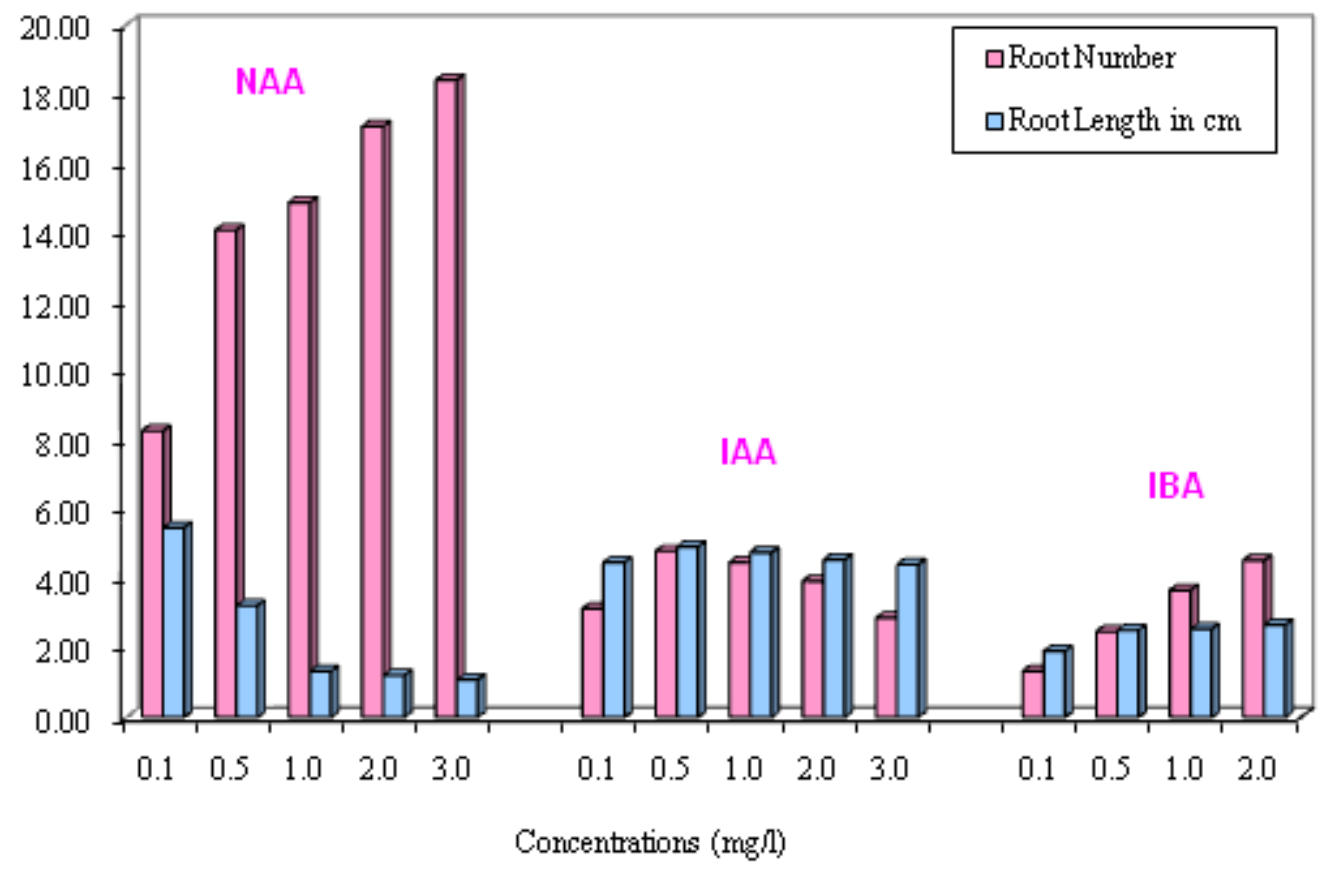

Figure 1: Rooting response of in vitro regenerated shoots of Caralluma lasiantha in half strength MS containing NAA, IAA and IBA in various concentrations with $1 \%$ sucrose after 25 days. 


\section{International Journal of Science and Research (IJSR) \\ ISSN (Online): 2319-7064}

Index Copernicus Value (2013): 6.14 | Impact Factor (2014): 5.611
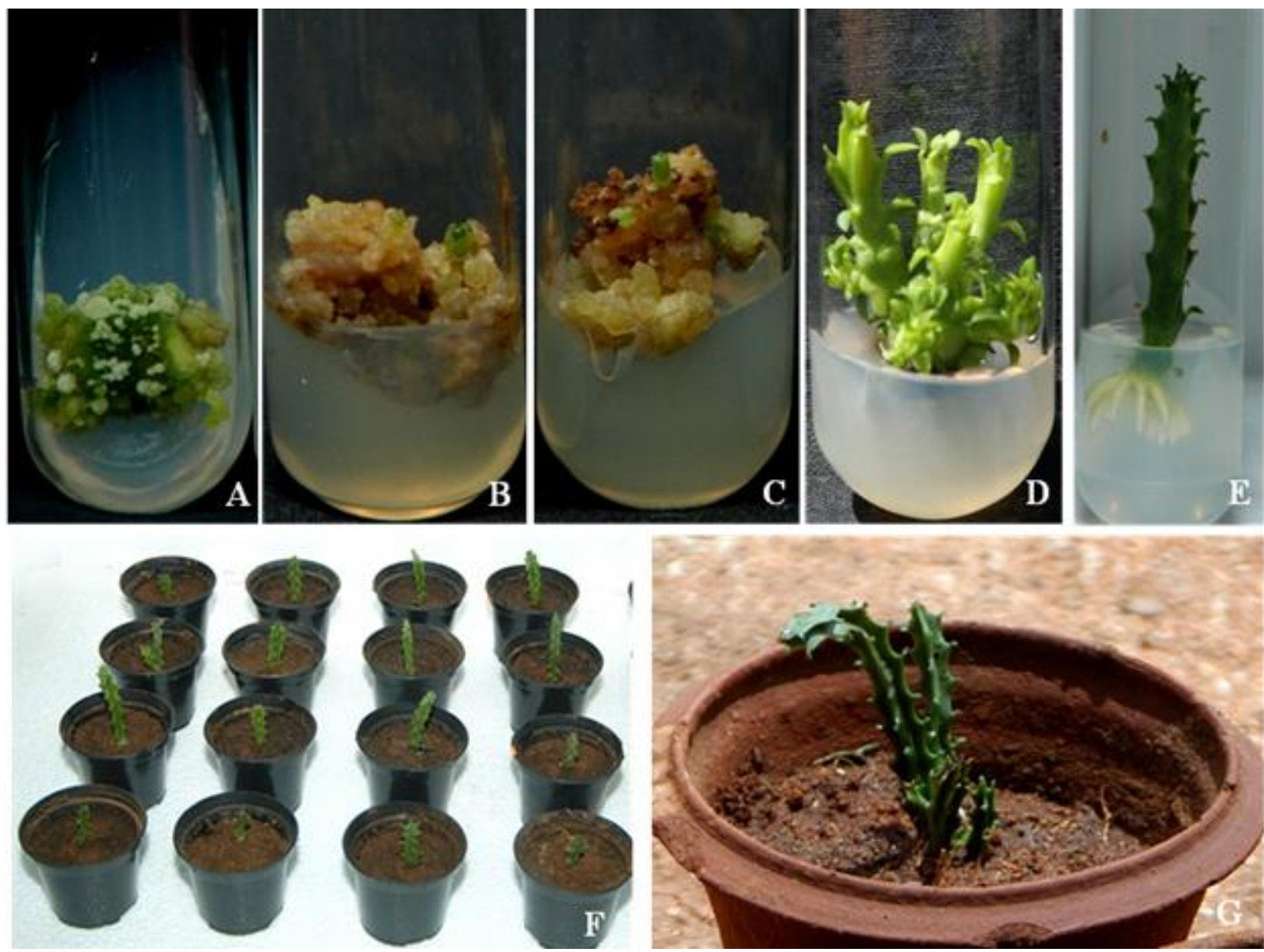

Figure 2: Callus induction, shoot regeneration, in vitro rooting and complete plant regeneration from stem segments of

Caralluma lasiantha.

A. Effect of 2,4-D 2mg/1 + BAP 0.1mg/1 on callus proliferation from stem segments cultured on MS medium. B. Shoot bud differentiation from callus when cultured on MS + BAP $1 \mathrm{mg} / 1+\mathrm{TDZ} 0.05 \mathrm{mg} / \mathrm{l}$. C. Shoot bud differentiation from callus when cultured on MS + BAP $1 \mathrm{mg} / 1+2 \mathrm{iP} 0.1 \mathrm{mg} / 1$. D. Multiplication of shoots on MS + BAP $1 \mathrm{mg} / 1+2 \mathrm{iP} 0.5 \mathrm{mg} / 1$. E. In vitro rooting of in vitro raised shoots on $1 / 2 \mathrm{MS}+\mathrm{NAA} 0.1 \mathrm{mg} / \mathrm{l}$. F. In vitro rooted plants transferred to containing peat moss, farmyard manure and soil. G. Acclimatized in vitro grown plant of Caralluma lasiantha 